\title{
Meslek Liselerinde Kaynaştırma Eğitimi Veren Branş Öğretmenlerinin Öz Yeterlilik Algılarının Çeşitli Değişkenler Açısından İncelenmesi*
}

Investigation of Self-Efficacy Perceptions of Branch Teachers Providing Inclusive Education in Vocational High Schools in Terms of Various Variables

\section{Serap ÖZ[1] Ecem GELENBE ÖZTÜRK[2]}

Bu araştırmanın amacı kaynaştırma öğrencilerinin eğitim gördüğü meslek liselerinde görev yapan 9. Sınıf branş öğretmenlerinin kaynaştırma eğitimine dair öz yeterlilik algılarını ortaya koymaktır. Araştırmanın çalışma grubunu 2018-2019 yılında İstanbul ili Çekmeköy ilçesinde bulunan meslek liselerinde 9. Sınıf kademesinde derse girmekte olan ve sinıflarında toplamda 48 adet kaynaştırma öğrencisi bulunan 94 branş öğretmeni oluşturmaktadır. Bu araştırma kapsamında öğretmenlere kişisel bilgi formu ve Kaynaştırma Uygulamalarında Öğretmen Yeterliliği Ölçeği uygulanmıştır. Ölçekler aracılığıyla toplanan nicel veriler SPSS 22.0 istatistik programı aracılığıyla analiz edilmiştir. Araştırmanın alt problemlerinin çözümlenmesinde Bağımsız Örneklem T-Testi, Tek Yönlü Varyans Analizi (ANOVA), LSD Testleri ve Korelasyon Testi kullanılmıştır. Araştırma bulgularına göre öğretmenlerin yaş, öğrenim durumu, kaynaştırma öğrencisi ile etkileşim, kaynaştırma eğitime ile ilgili eğitim alma durumu ile öğretmen yeterlilikleri arasında anlamlı bir fark bulunamamıştır. Bununla öğretmenlerin özel eğitim ile ilgili tecrübeleri ve mevzuat ile politikalara ilişkin bilgi düzeyleri ile öğretmen yeterlilikleri arasında anlamlı fark görülmüștür. Buna göre öğretmenlerin tecrübe ve mevzuata ve politikalara ilişkin bilgi düzeyleri arttıkça öğretmen yeterliliklerinin de arttığı bulgusuna ulaşılmıștır.

Anahtar Kelimeler: BEP, kaynaştırma sınıfları, kaynaştırma öğrencisi, mesleki eğitim, ortaöğretim, öğretmenlerin öz yeterlilik algıları

Received Date: 1 January 2021

The aim of this study is to reveal the self-efficacy perceptions of 9th grade branch teachers working in vocational high schools where inclusive students are educated. The study group of the research consists of 94 branch teachers who have been teaching at the 9 th grade in vocational high schools in Cekmeköy district of Istanbul in 2018-2019 and have a total of 48 students with special needs in their classes. Within the scope of this research, a personal information form and Teacher Competence Scale in Inclusive Practices were applied to teachers. The quantitative data collected through the scales were analyzed using the SPSS 22.0 statistical program. Independent Sample T-Test, One Way Analysis of Variance (ANOVA), LSD Tests and Correlation Test were used to investigate the sub-problems of the study. According to the findings of the research, no significant difference was found between teachers' age, graduation, interaction with the inclusive student, education status related to inclusive education and teacher competencies. Nevertheless, a significant difference was observed between the teachers' experiences of special education and their level of knowledge about legislation and policies with teacher competencies. Accordingly, it was found that as the experience and knowledge level of teachers about legislation and policies increased, teacher competencies also increased.

Keywords: IEP, inclusive classrooms, inclusive students, vocational education, self-efficacy perceptions of teachers, secondary education

* Bu çalışma Türkiye Bilimsel ve Teknolojik Araştırma Kurumu (TÜBİTAK) 4004 Doğa Eğitimi ve Bilim Okulları projesi kapsamında 2018/2 çağrı döneminde desteklenmiștir. Proje Numarası: 218B017

[1] Doktora Öğrencisi | Marmara Üniversitesi | Eğitim Bilimleri Enstitüsü | Eğitim Yönetimi ve Denetimi | İstanbul | Türkiye |ORCID: 0000-0002-7291-5934 | serapozyigit@gmail.com [2] Klinik Psikolog | MEB | İstanbul | Türkiye | ORCID: 000-0002-0188-4974 


\section{GíRiş}

$\dot{\mathrm{I}}$ nsan Hakları Evrensel Bildirgesi'nde de açıçca belirtilmiş olan "Her bireyin eğitim görme hakkı vardır" maddesi ile eğitimin temel ilkelerinden biri haline gelen fırsat eşitliği (İnsan Hakları Evrensel Bildirgesi, 2020) ve ülkemizde 1739 sayılı Milli Eğitim Temel Kanunun kapsamında yer alan "firsat ve imkan eşitliği" ibaresiyle yasalarımızca güvence altına alınmaktadır (Millî Eğitim Temel Kanunu, 1973). Bu ilkeler göz önünde bulundurulduğunda özel gereksinimli öğrencilerin de normal gelişim gösteren akranları ile aynı ortamda eğitim alarak ve onların yararlandığı eğitim-öğretim imkanlarından faydalanması gerekmektedir. Özel gereksinime ihtiyaç duyan bireyler terimi "aynı yaştaki birçok insanın aksine, öğrenmeyi ve eğitime erişimi zorlaştıran öğrenme güçlükleri veya engelleri olan çocukları ve gençleri" ifade etmektedir. Türkiye'de ise 1983 tarihli Özel Eğitime Muhtaç Çocuklar Kanunu 3. Maddesinde “özel eğitime muhtaç çocuklar" kavramı "Beden, zihin, ruh, duygu, sosyal ve sağlı özellikleri ve durumlarındaki olağan dışı ayrılıklar sebebiyle normal eğitim hizmetlerinden yararlanamayan 4-18 yaş grubundaki çocuklar” olarak tanımlanmaktadır (MEB, 1983). Bu öğrenciler bireysel ihtiyaçları çerçevesinde yarı zamanlı ve tam zamanlı kaynaştırma öğrencileri olarak örgün öğretim sınıflarında diğer akranlarıyla beraber eğitim görmektedir.

Kaynaştırma; özel eğitim gereksinimi olan bireylerin, normal gelişim gösteren akranları ile birlikte eğitim ve öğretimlerini devlete bağlı ve özel eğitim kurumlarında sürdürmeleri temeline dayanan, özel eğitim uygulamalarıdır (Varol, 2010). UNESCO (2003)’e göre kaynaştırma “öğrenmeye, kültürlere ve topluluklara katılımı artırarak ve eğitim dışında kalmayı azaltarak tüm çocukların, gençlerin ve yetişkinlerin ihtiyaçlarının çeşitliliğine hitap etme ve bunlara yanıt verme süreci” olarak tanımlanmaktadır. Millî Eğitim Bakanlığı Kaynaştırma/Bütünleştirme Yoluyla Eğitim Uygulamaları Genelgesi'nde (2017) kaynaştırma eğitiminin amacı, özel gereksinimi bulunan öğrencilerin tüm kademelerde normal gelişim gösteren akranları ile etkileşim içinde bulunmasını sağlamaktır. Kaynaştırma eğitimi aracılı̆̆ıyla bu bireylerinin dil, öz bakım, iletişimsel ve akademik beceriler yönünden en yüksek hedefe ulaşmalarını sağlayarak toplumla bütünleşmesi amaçlanmaktadır (MEB, 2017). Kaynaştırma eğitimi sürecinde bu öğrencilere bireysel özellikleri dikkate alınarak Bireyselleştirilmiş Eğitim Programı (BEP) uygulanması gerekmektedir. Bireyselleştirilmiş eğitim programı bir öğrenci için eğitim ortamına izlenecek bir ve ya birden fazla düzenlemenin yer aldığı yazılı programdır (MEB, 2004). Özel gereksinimli öğrencilerin ihtiyaçlarını karşılamak amacıyla yapılan eğitimin etkili ve verimli olması ancak BEP'in uygulanması ile mümkündür ve bu bağlamda kaynaştırma eğitiminin ayrılmaz bir parçasıdır (Fiscus ve Mandell, 2002).

Tarihsel olarak bakıldığında ilk uygulamaların 1970’li yıllarda Amerika Birleşik Devletleri'nde başladığı kaynaştırma eğitimi (Yazıcıoğlu, 2018), günümüzde birçok ülkenin eğitim politikasında yer almaktadır.1990'da düzenlenen "Herkes İçin Eğitim Dünya Konferansı", küresel olarak pek çok çocuğun uygun bir eğitime erişimden dışlandığı mevcut eğitim paradigmasına meydan okumaktadır. Buna göre etnik köken, din, cinsiyet, sosyoekonomik durum veya yeteneklere bakılmaksızın esnek ve kişiye özel programlama ve pedagojiyle tüm 
öğrencileri eğitime başarılı bir şekilde erişmesi mümkün olduğu vurgulanmaktadır (UNESCO, 1990). Dört yıl sonra yayınlanan Salamanca Bildirisi (UNESCO, 1994) bu kavramı daha da ileriye taşıyarak tüm öğrencilerin yerel okullarındaki normal sınıflarda eğitim almaları gerektiği fikrini desteklemektedir. 0 zamandan beri, son yirmi yılda kaynaştırma eğitiminin (Inclusive Education), amacını savunan küresel bir hareket artarak devam etmiștir. Ylllardan beri süregelen ve farklılıkları olan öğrencileri eğitim sisteminin dışına iten birçok uygulamaya bir cevap olarak gelişen bu hareket (Waitoller ve Artiles, 2013), sosyal adalete dayanan bir felsefenin ortaya çıkışına neden olmuştur (Dixon ve Verenikina, 2007). Wilkinson ve Pickett (2010), "eğitimsel eşitsizliğin azaltılmasının çok daha iyi bir topluma yol açtığını" belirterek bu uygulamanın, dezavantaj döngülerini kırmanın (Snow ve Powell, 2012) yanı sıra insanların becerilerini artırma, artan yenilik ve üretkenlik ve ardından uzun vadeli ekonomik uygulanabilirliğe yol açma potansiyeline sahiptir (OECD, 2010). $\mathrm{Bu}$ gelişmelerle beraber Dünya çapında okul sistemlerinde özel eğitim gereksinimi (Special Education Needs) olan öğrenci sayısı giderek artmaktadır (European Agency, 2020).

Ülkemizde kaynaştırma uygulaması 1983 tarihli ve 2916 sayılı "Özel Eğitime Muhtaç Çocuklar Kanunu” ile başlatılmıştır (Özel Eğitime Muhtaç Çocuklar Kanunu, 1983). Sonrasında, 573 sayılı Özel Eğitim Hakkında Kanun Hükmünde Kararname (1997) ve 2000 yllından itibaren uygulanmakta olan Özel Eğitim Hizmetleri Yönetmeliği'nin 2006, 2012 ve 2018 yıllarındaki düzenlemeleriyle son şeklini almıştır (Yazıcıŏ̆lu, 2018). Ülkemizde özel eğitim gereksinimi bulunan bireylere yönelik eğitim, özel rehabilitasyon merkezlerinin yanında zihinsel olarak eğitilebilir seviyede olan bireylerin topluma uyum sürecinde "kaynaştırma" uygulamaları adı altında 1992 yılından itibaren örgün eğitim veren özel ve devlet okullarında sürdürülmektedir (Varol, 2010).

Kaynaştırma eğitimini savunan araştırmacıların yaptığı çalıştırmalarda kaynaştırma uygulamasının özel gereksinimli öğrencilerin hem akademik hem de sosyal becerilerini geliştirdiği ve toplumsal yaşama daha iyi hazırladığı görülmektedir. Ayrıca kaynaştırma eğitimine tabi tutulan öğrencilerde toplumdan dışlanma sonucu oluşan olumsuz etkilerin minimum düzeyde oluştuğu gözlenmiştir (Farrell, 2000; Karagiannis ve diğerleri, 1996). Ahsan ve Sharma (2018), De Leeuw ve diğerleri, (2018), Mulholland ve Cumming (2016) ve Saloviita (2020), kaynaştırma eğitiminin öğrencilerin duyuşsal gelişimi üzerindeki olumlu etkisini vurgulamaktadırlar. Öğretmenler açısından değerlendirildiğinde ise kapsayıcı sınıflarda öğretim yapmanın bir sonucu olarak, mesleki becerilerin geliştiği belirtilmektedir. Bu uygulama sonucunda normal gelişim gösteren öğrencilerin engelli bireylere karşı daha olumlu tutumlar geliştirmeleri ve eşitliğe dayalı sosyal ilkeler oluşturma ve daha uyumlu bir toplumu teşvik etme olasılıklarının artması gibi toplumsal faydalar ön plana çımaktadır (Begeny ve Martins, 2007; Karagiannis ve diğerleri. 1996). Bu bağlamda kaynaştırma eğitiminin etkili ve verimli bir şekilde uygulanması önem arz etmektedir (Bayar, 2015). Kaynaştırma eğitiminin etkili olarak sürdürülmesi için okullarda çeşitli düzenlemeler yapılması gerekmektedir (Rosenberg, Westling ve McLeskey, 2008). Öğretimin bireyselleştirilmesi kapsamında yapılan düzenlemeler fiziksel düzenlemeler, sınıf ortamına ve iklimine yönelik düzenlemeler, öğretimsel ve işleyişe yönelik düzenlemeler gibi çok boyutlu bir süreçtir (Smith, Polloway, Patton ve Dowdy, 2008). Öğretimsel ve sınıf iklimine ilişkin düzenlemeler öğretmenlerin, öğrenci ihtiyaçlarını 
tanımlayıp, karşılamaya yönelik eğitim programında, öğretimsel hedeflerde, öğretim yöntem ve tekniklerinde uyarlamalar yapabilmelerini gerektirmektedir (Kargın, Güldenoğlu ve Şahin, 2010). Bu konuda özel olarak eğitilmiş personelin gerekliliği, her okulun seviyesine ve türüne bağlıdır. Öğretmen yetiştirme müfredatı da bu konuda çok önemli bir rol oynamaktadır. Örneğin, İspanya'daki öğretmen adayları, özel gereksinimli öğrencilerini doğru ve profesyonel bir şekilde geliştirmede yetkin hale gelebilmeleri için ek bir yıl boyunca özel eğitim kursları alma fırsatından yararlanırlar (Lasagabaster ve Zarobe, 2010). İngiltere'de özel gereksinimli öğrencilerin eğitimi için içinde öğretmenler, sağlık çalışanları, aile ve diğer uzmanların olduğu bir bireysel eğitim planı oluşturulmaktadır (Çetin, 2020). Japonya'da ise kaynaştırma eğitimde başarı artışını sağlamak için 2017'den itibaren öğretmen eğitimlerini iyileştirme çabalarında bulunulmuştur ve öğretmen yetiştirme müfredatına bu konuda eklemeler yapılmıştır (MEXT, 2017). Finlandiya'da özel eğitim gereksinimli bireyler için dersler bu alanda yüksek lisans derecesine sahip sınıf öğretmenleri tarafından verilmektedir. Çin'de özel gereksinimli öğrencilerin eğitimi konusu evrenselleștirmenin ana stratejilerinden birisi olarak kabul edilmektedir (Deng ve Manset, 2000). Kaynaştırma eğitimi veren öğretmenlerin kendilerini bu konuda yetersiz hissettiklerini belirttiği (Forlin, 2010), Hong Kong'da devlet öğretmenlerin \%10'una eğitim sağlayarak bu problemi çözmeye yönelik adımlar atılmaktadır (Sin, Tsang, Poon ve Lai, 2010).

Öğretmenlerin ve okul yönetiminin kaynaştırma eğitimi konusundaki görüşlerini ülkemiz açısından değerlendiren çalışmalarda İra ve Ayan (2016)'a göre kaynaştırma öğrencisi olan öğretmenlerin kaynaştırma eğitimine destek sağlama oranı yalnızca \%29'dur. Okul yönetimi tarafından kaynaştırma eğitimine destek sağlama oranı \%11.8 iken, \%58.8 gibi bir oran kısmen destek sağlamaktadır. Okul yöneticilerinin ise sadece \%38.2'si okullarında özel gereksinimli öğrencilerinin ihtiyaçları doğrultusunda eğitim desteği verildiğini belirtmişlerdir. Pektaş (2008)'a göre özel eğitim programı mezunlarının \% 21.7'si, farklı alan mezunlarının \% 16.6'sının kaynaştırma eğitiminde Bireyselleștirilmiş Eğitim Programı kullanmaktadır. Her iki programdan mezun öğretmenlerin bireyselleştirilmiş eğitim programı kullanın oranı \%50'den daha azdır. Özel eğitim mezunu öğretmenlerin bile yetersiz kaldığı (Pektaş, 2008) bireyselleştirilmiş eğitim programlarının uygulanması hususunda, Kuyumcu (2011) kaynaştırma eğitimi veren sınıf ve rehber öğretmenlerinin çeşitli nedenlerle sorun yaşadığını belirtmektedir. Bu sorunlar özellikle öğrencinin performansını değerlendirmede, hedeflerin belirlenmesinde, ailelerle işbirliği konusunda, destek hizmetlerin ile eğitimsel uygulama ve planlama, ilgili kaynaklara ulaşmada, amaçların değerlendirilmesinde ve öğrencinin arkadaşları tarafından kabulü gibi birçok başlıkta olabilmektedir. Metin (2007)'e göre ilköğretim öğretmenlerinin birçoğu kaynaştırma uygulamaları ve ilgili mevzuat konusunda bilgi eksikliği yaşamakta ve bu konuda eğitime ihtiyaçları olduklarını belirtmektedir. Ünal, Iflazoğlu ve Saban (2017) her 10 öğretmenden sadece birisinin kaynaştırma uygulamaları konusunda bilgi sahibi olduğunu ve birçoğunun kaynaştırma eğitimi konusunda nasıl bir yol izleyecekleri konusunda fikir sahibi olmadığını belirtmektedir. Akalın, Sucuoğlu ve Sazak (2008), öğretmenlerin kaynaştırma sınıflarında önleyici sınıf yönetimi konusunda desteğe ihtiyacı olduğunu belirterek özellikle sınıfların içerisine girerek yapılacak detaylı araştırmaların öğrenci ve öğretmen gereksinimlerini daha doğru tespit etmek adına gerekli olduğu görüşünü öne sürmüşlerdir. Alan yazında yapılan diğer çalışmalarda 
öğretmenlerin kaynaştırma eğitimi konusundaki mesleki yeterliliklerinin sınırlı olduğunu göstermektedir (Çerezci, 2015; Gezer, 2017; Gök ve Erbaş, 2011; Karaca, 2018). Özcan (2020) tarafından yapılan araştırmada öğretmenleri yaşları ilerledikçe kaynaştırma eğitimine ilişkin kaygı düzeylerinin arttı̆̆ı ancak kaynaştırma sınıflarında ders verme tecrübesi arttıkça kaygı düzeylerinin azaldığı görülmektedir.

Meslek liseleri bağlamında yapılan çalışmalar incelendiğinde ise Şen (2016) kaynaştırma eğitiminin başarılı olmasındaki en önemli noktanın öğretmenin özverili çalışmasına bağlı olduğunu belirtmektedir. Özellikle meslek liselerinde müfredatın zorluğu ve ders sayısının fazlalığı hem öğretmeni hem de öğrenciyi yoran bir unsur olduğundan öğretmenleri bu konuda rahatlatıcı tedbir alınması gerektiğini öne sürmektedir. $\mathrm{Bu}$ bağlamda ülkemizde öğretmenlerin kaynaştırma uygulamalarına yönelik hizmet içi eğitim almaları ve özel gereksinimli öğrencilerin bireysel ihtiyaçlarına yönelik nasıl eğitim vermeleri gerektiği hususunda bilgilendirilmeleri gerekmektedir (Șen,2016). Paloshi ve diğerleri (2014) mesleki eğitim bağlamında kaynaştırma eğitimini değerlendirmek amacıyla yaptıkları çalışmada özel eğitime ihtiyacı olan öğrencilerin gelişimi hakkında deneyim alışverişinde bulunmak için eğitime dahil etme ekibiyle ve diğer öğretmenlerle ve ebeveynlerle işbirliğinin önemine değinerek öğrencinin kişisel özelliklerinin bireyselleştirilmiş eğitim planı yapılırken mutlaka dikkate alınması gerektiğini vurgulamaktadırlar.

\section{Çalışmanın Önemi ve Amacı}

Kaynaştırma öğrencilerinin ağırlıklı olarak bulunduğu meslek liselerinde özel eğitim öğretmeni kadrosu bulunmamaktadır. Kaynaştırma eğitimi kapsamındaki öğrenciler özel eğitim konusunda uzmanlık bilgisi olan ilçe Rehberlik Araştırma Merkezleri ve Okul Rehber öğretmenleri tarafından takip edilseler de okul içerisindeki zamanlarının neredeyse tamamını sınıf rehber öğretmenleri ve branş derslerine giren öğretmenlerle geçirmektedirler. Diğer öğrencilerden farklı özellikler gösteren bu bireylerin eğitimi esnasında özel eğitim konusundaki bilgisi oldukça sınırlı olan branş öğretmenleri bir hayli sorun yaşamaktadır. Öğretmenlerin kaynaştırma öğrencilerin tanılarıyla ilgili bilgileri yetersiz olduğu için eğitim öğretim, velilerle iletişim, Bireyselleştirilmiş Eğitim Programı (BEP) hazırlama, kaynaştırma öğrencilerinin mesleki yönlendirmeleri gibi konularda yönlendirmeye duydukları ihtiyaç okul rehberlik servisleri ve idarelerince gözlenmektedir. Kaynaştırma uygulamasının başarısında en önemli unsurlardan birisi öğretmendir (Batu, 2000). Özellikle lise çağındaki çocuklarda ergenliğin getirdiği problemlerle birlikte başlı başına bir uzmanlık gerektiren kaynaştırma eğitimi öğretmenlerin bu konudaki bilgi yetersizliği ile birleşmesi halinde önemli bir sorun haline gelebilmektedir. Bu çalışmanın amacı Meslek lisesinde 9. Sınıf kademesinde kaynaştırma sınıflarında görev yapan branş öğretmenlerinin kaynaştırma eğitimi konusundaki öz yeterlilik algılarının çeşitli değişkenler açısından incelenmesidir.

Bu temel amaç doğrultusunda aşağıdaki sorulara yanıt aranmak istenmiştir:

1. Meslek liselerinde kaynaştırma sınıflarında görev yapan branş öğretmenlerinin kaynaştırma eğitimine ilişkin yeterlik düzeyi algısı nedir? 
2. Meslek lisesinde kaynaştırma sınıflarında görev yapan branş öğretmenlerinin

2.1. yaș,

2.2. öğrenim durumu

2.3. Özel eğitime ihtiyaç duyan birey ile etkileşim durumu

2.4. özel eğitim ile ilgili eğitim alma düzeyi,

2.5. özel eğitime ihtiyaç duyan öğrencilere eğitim verme tecrübesi,

2.6. özel eğitime ilişkin politikalar ve mevzuatlara ilişkin bilgi düzeyi

değișkenlerine göre kaynaștırma uygulamalarında öğretmen yeterlilikleri arasında anlamlı fark var midır?

3. Meslek lisesinde kaynaştırma sınıflarında görev yapan branş öğretmenlerinin kaynaştırma eğitimine yönelik etkileşim, eğitim, tecrübe ve mevzuat bilgisi ile kaynaştırma uygulamalarında öğretmen özyeterlilik algıları arasında anlamlı ilişki var mıdır?

\section{YÖNTEM}

\section{Araştırma Deseni}

Araștırmada bağımlı ve bağımsız değișkenler arasındaki ilişkiyi betimsel yöntemle incelenerek ilişkisel tarama modeli kullanılmıştır. İki veya daha fazla değişken arasında değişim durumunu ve kademesini belirlemeyi amaçlayan bir araştırma modeli olan ilişkisel tarama yönteminde veriler arasındaki ilişki (Karasar, 2006) karşllaştırma yöntemiyle gösterilmektedir.

\section{Çalışma Grubu}

$\mathrm{Bu}$ araştırmanın çalışma grubunu 2018-2019 eğitim öğretim yılında İstanbul Çekmeköy ilçesinde meslek liselerinde 9. Sınıf kademesindeki kaynaştırma sınıflarında görev yapmakta olan 94 branş öğretmenidir. Araştırmaya katılan öğretmenlerin (n=94) sosyodemografik özellikleri Tablo 1'de verilmiştir.

\section{Tablo 1}

Katılımcıların sosyodemografik özelliklere göre dağılımı

\begin{tabular}{llcc}
\hline & Gruplar & n & \% \\
\hline \multirow{3}{*}{ Yaş } & 25 yaş altı & 3 & 3.2 \\
& $26-35$ Yaş & 34 & 36.2 \\
\multirow{2}{*}{ Cinsiyet } & $36-45$ Yaş & 43 & 45.7 \\
Ĕgitim Durumu & 46 Yaş Üstü & 14 & 14.9 \\
& Kadın & 68 & 72.3 \\
& Erkek & 26 & 27.7 \\
& Lisans & 70 & 74.5 \\
\hline
\end{tabular}


Tablo-1 incelendiğinde katılımcıları büyük çoğunluğunu 26-45 (\% 82) yaş aralığında bulunan katılımcıların oluşturduğu görülmektedir. Katılımcıları 68'i (\%72.3) kadın ve 26'sı (\%27.7) erkektir. Araştırmaya katılan okul öğretmenlerin 70’i (\%74.5) lisans ve 24’ü (\%25.5) yüksek lisans mezunudur.

\section{Veri Toplama Araçları}

$\mathrm{Bu}$ araştırmada veri toplama araçları olarak "Kişisel Bilgi Formu" ve Kaynaştırma Uygulamalarında Öğretmen Yeterliliği ölçeği (KUÖYÖ) kullanılmıştır.

Kişisel Bilgi Formu. Bu araştırmada katılımcıların yaş, cinsiyet ve eğitim durumu, özel eğitim konusunda aldıkları eğitim, özel eğitim gereksinimi olan bireyler ile kayda değer bir etkileşim, özel eğitim verme tecrübesi ve özel eğitim konusundaki politika ve mevzuata ilişkin bilgi düzeyini kapsayan bir kişisel bilgi formu kullanılmıștır. Katılımcıların kimlik ve özel bilgilerine yönelik herhangi bir soru sorulmamıştır.

Kaynaştırma Uygulamalarında öğretmen Yeterliliği ölçeği. Bu araştırmada Kaynaştırma Uygulamalarında Öğretmen Yeterliliği ölçeği (KUÖYÖ) kullanılmıştır. Sharma, Loreman ve Forlin (2011) tarafından geliştirilen ölçek toplamda 18 maddeden oluşmaktadır. Likert tipi olan ölçekte 1-6 puan arası, (Kesinlikle Katılmıyorum, Katılmıyorum, Kısmen Katılmıyorum, Kısmen Katılıyorum, Katılıyorum, Kesinlikle Katılıyorum) seçenekleri yer almaktadır. Ölçekten alınabilecek minimum ve maksimum puanlar 18 ve 108 arasıdır. Puanlar yükseldikçe bireyin kaynaştırma eğitimi uygulamalarındaki yeterlik algısının yükseldiği görülmektedir. Kaynaştırma Uygulamalarında Öğretmen Yeterliği Ölçeğinin (KUÖYÖ) Cronbach Alpha testi ile yapılmış olan Türkçe formunun güvenirlik çalışmasında Cronbach Alpha testi sonucu .89 olarak bulunmuştur. Ölçeğin alt boyutlarının güvenirlik çalışması için uygulanan Cronbach Alpha testi sonuçlarına göre değerler "Kaynaştırma Eğitiminde Öğretim Yeterliği" alt boyutunda .88, "Kaynaştırma Eğitiminde İşbirliği Yeterliği” alt boyutunda 90 ve "Kaynaştırma Eğitiminde Sınıf Yönetimi Yeterliği" alt boyutunda .86 olarak bulunmuştur. Bu değerler ölçeğin Türkçeye uyarlanmış formunda güvenirliğin yeterli düzeyde olduğunu göstermektedir (Bayar, 2015). Yapılan bu çalışmanın güvenilirlik çalışmasında Cronbach Alpha testi sonuçlarına göre değerler "Kaynaştırma Eğitiminde Öğretim Yeterliği" alt boyutunda .74, "Kaynaştırma Eğitiminde İşbirliği Yeterliği” alt boyutunda .79 ve "Kaynaştırma Eğitiminde Sınıf Yönetimi Yeterliği" alt boyutunda 86 olarak bulunmuştur yapılarak ölçeğin genel iç tutarlık katsayısı .88 olarak bulunmuştur.

\section{Verilerin Analizi}

Çalışma grubundaki verilerin istatistiksel değerlendirilmesinde IBM SPSS Statistical 22.0 programı kullanılmıştır. Tanımlayıcı istatistikler "ortalama \pm standart sapma, sayı ve yüzde" olarak ifade edilmiştir. Elde edilen verilerin çarpıklık ve basıklık değerlerine bakılarak normal dağılım gösterip göstermediği belirlenmiștir. Elde edilen sonuca göre araştırma değişkenleri normal dağılım göstermiştir. Bu sebeple parametrik testler kullanılmasına karar verilmiştir. "Bağımsız Örneklem T-Testi, Tek Yönlü Varyans Analizi (ANOVA) ile LSD PostHoc Testleri ve Pearson Çarpım Momentler Korelasyon katsayısı analizi uygulanmıştır. İstatistiksel anlamlılık sınırı olarak $(\mathrm{p}<0.05)$ değeri kabul edilmiştir. 


\section{Verilerin Toplanması}

Bu çalışma verileri 14 Şub. 2019 tarihinde çalışmanın yürütüldüğü İstanbul/Çekmeköy İlçe Milli Eğitim Müdürlüğü aracılığıyla kaymakamlıktan gerekli kurumsal izinler alınarak ilçedeki meslek liselerinde kaynaştırma eğitimi verilen 9. Sınıflarda derse girmekte olan öğretmenlerden toplanmıștır. Araştırmada kullanılan ölçekler bu araştırmanın yapıldığı proje kapsamında "Türkiye Bilimsel ve Teknolojik Araştırma Kurumu" (TÜBİTAK) tarafından resmi yazışmalar ile onaylanmış ve verilerin gizliliğine dikkat edilmesi hususu koşuluyla etik kurul onayına gerek olmadığı belirtilmiştirAraştırmacılar tarafından oluşturulan formda çalışmaya katılım koşulları ve çalışmayı istedikleri zaman bırakabileceklerine dair bilgilendirmeler yer verilmiştir. Araştırma kapsamında 103 öğretmen ile bir toplantı gerçekleştirilmiş ve ölçekler dağıtılmıştır. Bu süreçte katılımcılardan herhangi bir kişisel bilgi istenmemiştir. 9 öğretmen araştırmaya katılmak istemediği için araştırmaya 94 öğretmen ile devam edilmiştir.

\section{Verilerin Analizi}

Araştırma kapsamında çalışma grubundan toplanan veriler SPSS 22.0 programına aktarılmıştır. Araştırmada kullanılan veri toplama araçları ile elde edilen verilerin yorumlanması için betimsel istatistikten yararlanılmıştır. Elde edilen bulgular ve yorumları Tablo 2'de gösterilmektedir.

\section{BULGULAR ve YORUM}

\section{Tablo 2}

Veri toplama araçlarından elde edilen betimsel istatistikler

\begin{tabular}{lccc}
\hline & Gruplar & $\mathbf{n}$ & $\mathbf{\%}$ \\
\hline \multirow{2}{*}{ Özel Eğitim Konusunda Eğitim } & Hiç & 73 & 77.7 \\
& Biraz & 17 & 18.1 \\
Etkileşim & Üst 40+saat & 4 & 4.3 \\
\hline & Evet & 53 & 56.4 \\
& Hayı̀r & 41 & 43.6 \\
\hline \multirow{2}{*}{ Mevzuat Bilgisi } & Hiç & 27 & 28.7 \\
& zayılf & 36 & 38.3 \\
& orta & 29 & 30.9 \\
Tecrübe & iyi & 2 & 2.1 \\
& Hiç & 38 & 40.4 \\
& Orta & 42 & 44.7 \\
\hline
\end{tabular}

Tablo 2'de görüldüğü gibi tamamı kaynaştırma öğrencisine ders vermekte olan katılımcıların \%77'si (n=73) özel eğitim konusunda herhangi bir eğitim almamıştır. 94 katılımcıdan sadece 4 tanesi özel eğitim konusunda 40 saatin üzerinde bir eğitim aldığını belirtmektedir. Özel eğitime ihtiyaç duyan bireyler ile kayda değer etkileşim sorusunda ise katılımcıların \%56’sı (n=53) evet yanıtını vermiştir. Özel eğitime dair politikalar ve mevzuat bilgisine ilişkin soruda katılımcıların sadece \%2'si iyi düzeyde bilgi sahibi olduğunu belirtmektedir. 
Özel eğitime ilişkin tecrübeyle ilgili soruda katılımcıların \%43’ü bu konuda hiç tecrübesi olmadığını belirtmektedir. Araştırmanın birinci alt problemine yönelik bulgular aşağıda verilmektedir.

\section{Meslek liselerinde kaynaştırma sınıflarında görev yapan branş öğretmenlerinin kaynaştırma eğitimine ilişkin yeterlik algıları ne düzeydedir?}

$\mathrm{Bu}$ alt problemde araştırmada kullanılan "Meslek lisesinde görev yapan branş öğretmenlerinin Kaynaştırma Uygulamalarında Öğretmen Yeterlilikleri” ölçeğinin betimsel değişkenlere göre farklarını incelemek amacıyla yapılan analizde verilerin normal dağılım gösterdiği tespit edilmiştir. Araştırmanın birinci alt problemi olan "Meslek lisesinde kaynaştırma sınıflarında görev yapan branş öğretmenlerinin kay naștırma eğitimine ilişkin algılanan öz-yeterlikleri ne düzeydedir ?" sorusuna ilişkin bulguların normallik testi sonuçları ve betimsel analizi Tablo 3' ve Tablo 4'te verilmiştir.

\section{Tablo 3}

Normallik testi sonuçları

\begin{tabular}{lcccc}
\hline & mod & medyan & çarpıklık & basıklık \\
\hline Kaynaştırma Eğitimde Öğretim Yeterliği & 29 & 29 & -.954 & -1.057 \\
Kaynaştırma Eğitimde İşbirliği Yeterliği & & & -.929 & 1.059 \\
Kaynaştırma Eğitimde Sınıf Yönetimi & 29 & 27.50 & -.763 & -.626 \\
Kaynaştırma Eğitimde Genel Yeterlik & 29 & 28 & 0.88 \\
\hline
\end{tabular}

Bir ölçekte çarpıklık ve basıklık katsayılarının -1.5 ile +1.5 aralığında olmasının verilerin normal dağılım gösterdiği şeklinde yorumlanmaktadır (Tabachnick ve Fidell, 2013). Yukarıdaki değerlere göre veriler normal dağılım gösterdiğinden; bağımsız örneklem t-testi, ikiden fazla gruplarda ise tek yönlü varyans analizi (ANOVA) testi kullanılmıştır. Elde edilen bulgular \%95 güven aralığında, \%5 anlamlılık düzeyinde değerlendirilmiştir. İstatistiksel anlamlılık sınırı olarak $(\mathrm{p}<0.05)$ değeri kabul edilmiștir.

\section{Tablo 4}

Kaynaştırma uygulamalarında öğretmen yeterlik ölçeğinden elde edilen betimsel istatistikler

\begin{tabular}{lccccc}
\hline & $\mathbf{n}$ & $\overline{\mathbf{x}}$ & $\mathbf{S s}$ & Min. & Max. \\
\hline Kaynaştırma Eğitimde Öğretim Yeterliği & 94 & 27.34 & 3.93 & 14 & 35 \\
Kaynaştırma Eğitimde İşbirliği Yeterliği & 94 & 26.43 & 4.51 & 12 & 35 \\
Kaynaștırma Eğitimde Sını Yönetimi & 94 & 28.57 & 4.48 & 11 & 36 \\
Kaynaştırma Eğitimde Genel Yeterlik & 94 & 78.11 & 10.69 & 51 & 98 \\
\hline
\end{tabular}

Tablo 4'e göre öğretmenlerin toplam 36 puan üzerinde değerlendirilen alt boyutlarda elde edilen puan ortalamaları sırasıyla "Kaynaştırma Eğitiminde Öğretim Yeterliği" alt boyutu için 27.34, "Kaynaştırma Eğitiminde İşbirliği Yeterliği” alt boyutu için 26.43, "Kaynaştırma Eğitiminde Sınıf Yönetimi Yeterliği" alt boyutu için 28.57 olarak bulunmuştur. "Kaynaştırma Eğitiminde Genel Yeterlik" puanları ortalaması ise 108 puan üzerinden 78.11 olarak elde edilmiştir. Elde edilen puanların alt boyuta yer alan madde sayısı ile bölümünden elde edilen ortalamalar incelendiğinde genel yeterlik ve alt boyutlara ilişkin puan aralığı 6.00-4.34 
aralığındadır. Bu bağlamda öğretmenlerin kendilerini yüksek yeterlikte tanımladıkları görülmektedir. Araştırmanın ikinci alt problemine yönelik bulgular aşağıda verilmektedir.

\section{Meslek lisesinde kaynaştırma sınıflarında görev yapan branş öğretmenlerinin çeşitli değişkenlere göre öğretim yeterlilik algıları ne düzeydedir?}

$\mathrm{Bu}$ alt problemde araştırmada kullanılan "Meslek lisesinde görev yapan branş öğretmenlerinin Kaynaştırma Uygulamalarında Öğretmen Yeterlilikleri” ölçeğinin betimsel değişkenlere göre farklarını incelemek amacıyla yapılan analizde verilerin normal dağılım gösterdiği tespit edilmiş olup bu alt probleme ilişkin grup istatistikleri tek yönlü varyans analizi (ANOVA) ve bağımsız örneklem t- testi çalışmaları ile gerçekleștirilmiştir. Elde edilen bulgular ve yorumları bu bölümde yer almaktadır

Yaş değişkenine göre. Bu değişkene göre alt problem "Meslek lisesinde görev yapan branş öğretmenlerinin yaş değişkenine göre kaynaştırma uygulamalarında öğretmen yeterlilikleri algıları arasında fark var mıdır?” şeklindedir. Bu alt probleme göre grup istatistikleri Tablo 5’de gösterilmektedir.

\section{Tablo 5}

Öğretmenlerinin kaynaştırma uygulamalarında öğretmen yeterliliklerinin yaş değişkenine göre ANOVA sonuçları

\begin{tabular}{llccccc}
\hline Ölçek & \multicolumn{1}{c}{ Yaș } & Kareler Top. & df & Kareler Ort. & $\boldsymbol{F}$ & $\boldsymbol{p}$ \\
\hline \multirow{2}{*}{ Öğretmen Yeterlilikleri } & Gruplar Arası & 595.19 & 3 & 198.39 & & \\
& Gruplar İçi & 10048.52 & 90 & 111.65 & 1.777 & .157 \\
& Toplam & 10643.71 & 93 & & & \\
\hline
\end{tabular}

Tablo 5’e bakıldığında, grup ortalamaları farkının anlamlı olup olmadığına ilişkin verileri elde etmek amacıyla yapılan ANOVA analizi sonucunda; araștırmadaki öğretmenlerinin Kaynaştırma Uygulamalarında Öğretmen Yeterlilikleri (F=1.777, p>.05) ölçeğinde yaş değişkenine göre .05 anlamlılık düzeyinde anlamlı farklılaşma olmadığı bulgusuna ulaşılmıştır.

Öğrenim durumu değişkenine göre. Bu değişkene göre alt problem "Meslek lisesinde görev yapan branş öğretmenlerinin öğrenim durumu değişkenine göre kaynaştırma uygulamalarında öğretmen yeterlilikleri arasında fark var mıdır?" şeklindedir. Bu alt probleme göre grup istatistikleri Tablo 6'de gösterilmektedir.

\section{Tablo 6}

Öğretmenlerinin kaynaştırma uygulamalarında öğretmen yeterliliklerinin öğrenim durumu değişkenine göre bağımsız örneklem t-testi sonuçları

\begin{tabular}{llccccc}
\hline Ölçek & \multicolumn{1}{c}{ Öğrenim Durumu } & $\boldsymbol{n}$ & $\overline{\boldsymbol{x}}$ & $\boldsymbol{s}$ & \multicolumn{1}{c}{$\boldsymbol{t}$} & $\boldsymbol{p}$ \\
\hline Öğretmen Yeterlilikleri & Lisans & 70 & 77.42 & 11.43 & & \\
& Yüksek Lisans & 24 & 80.12 & 8.07 & & .121 \\
\hline
\end{tabular}

Tablo 6'e bakıldığında, yapılan "bağımsız örneklem t testi” sonucuna göre, araştırmaya katılan öğretmenlerinin Kaynaştırma Uygulamalarında Öğretmen Yeterlilikleri (t=-1,066, p>.05) ölçeğinde 
öğretmenlerin öğrenim durumu değişkenine göre .05 anlamlılık düzeyinde farklılaşma olmadı̆̆ bulgusuna ulaşılmıştır.

Etkileşim değişkenine göre. Bu değişkene göre alt problem "Meslek lisesinde görev yapan branş öğretmenlerinin özel eğitime ihtiyaç duyan bireylerle etkileşim” değişkenine göre kaynaştırma uygulamalarında öğretmen yeterlilikleri arasında fark var mıdır?” şeklindedir. Bu alt probleme göre grup istatistikleri Tablo 7'de gösterilmektedir.

\section{Tablo 7}

Öğretmenlerin kaynaştırma uygulamalarında öğretmen yeterliliklerinin etkileşim değişkenine göre bağımsız örneklem t-testi sonuçları

\begin{tabular}{lcccccc}
\hline Ölçek & Cevaplar & $\mathbf{n}$ & $\overline{\mathbf{x}}$ & Ss & $\mathbf{t}$ & $\mathbf{p}$ \\
\hline \multirow{2}{*}{ Öğretmen Yeterlilikleri } & Evet & 53 & 79.16 & 9.57 & \multirow{2}{*}{1.086} & .086 \\
& Hayır & 41 & 76,75 & 12 & & \\
\hline
\end{tabular}

Tablo 7'e bakıldığında, yapılan "bağımsız örneklem t testi” sonucuna göre, araştırmaya katılan öğretmenlerinin Kaynaştırma Uygulamalarında Öğretmen Yeterlilikleri ( $t=-1,086, p>.05)$ ölçeğinde özel eğitime ihtiyaç duyan birey ile anlamlı etkileşimde bulunma değişkenine göre .05 anlamlılık düzeyinde farklılaşma olmadığı bulgusuna ulaşılmıştır.

Eğitim Alma değişkenine göre. Bu değişkene göre alt problem "Meslek lisesinde görev yapan branş öğretmenlerinin özel eğitim ile ilgili eğitim alma değişkenine göre kaynaştırma uygulamalarında öğretmen yeterlilikleri arasında fark var mıdır?" şeklindedir. Bu alt probleme göre ANOVA analizi sonuçları Tablo 8'de gösterilmektedir.

\section{Tablo 8}

Öğretmenlerinin kaynaştırma uygulamalarında öğretmen yeterliliklerinin özel eğitime ilişsin eğitim alma değişkenine göre ANOVA sonuçları

\begin{tabular}{llccccc}
\hline Ölçek & Eğitim Alma & Kareler Top. & df & Kareler Ort. & F & p \\
\hline \multirow{2}{*}{ Öğretmen Yeterlilikleri } & Gruplar Arası & 297.982 & 2 & 148.99 & & \\
& & & & & 1.311 & .353 \\
& Gruplar İçi & 10345.73 & 91 & 113.68 & & \\
& Toplam & 10643.71 & 93 & & & \\
\hline
\end{tabular}

$* \mathrm{p}<.05$

Tablo 8'ya bakıldığında, ortalamalar arası farkın anlamlı olup olmadığına ilişkin veri elde etmek amacıyla yapılan ANOVA analizi sonucunda; araştırmadaki öğretmenlerinin Kaynaştırma Uygulamalarında Öğretmen Yeterlilikleri ( $\mathrm{F}=1.311, \mathrm{p}>.05$ ) ölçeğinde yaş değişkenine göre. 05 anlamlılık düzeyinde farklılaşma bulunmadığı belirlenmiştir.

Özel gereksinimli öğrencilere eğitim verme tecrübesi değişkenine göre. Bu değişkene göre alt problem "Öğretmenlerin özel eğitime ihtiyaç duyan öğrencilere eğitim verme tecrübesi değişkenine göre 
kaynaştırma uygulamalarında öğretmen yeterlilikleri arasında fark var mıdır?" şeklindedir. Bu alt probleme göre grup ANOVA analizi sonuçları Tablo 9'da ve “LSD Post Hoc testi” Tablo 10’de yer almaktadır.

\section{Tablo 9}

Öğretmenlerinin kaynaștırma uygulamalarında öğretmen yeterliliklerinin özel gereksinimli öğrencilere eğitim verme tecrübesi değişkenine göre ANOVA sonuçları

\begin{tabular}{llccccc}
\hline Ölçek & Özel Eğitim Tecrübe & Kareler Top. & df & Kareler Ort. & F & p \\
\hline \multirow{3}{*}{ Öğretmen Yeterlilikleri } & Gruplar Arası & 2106.46 & 2 & 1053.23 & & \\
& Gruplar İçi & & & & \multirow{2}{*}{11.227} & .000 \\
& Toplam & 8537.24 & 91 & 93.81 & & \\
\hline
\end{tabular}

$* p<.05$

Tablo 9'ya bakıldığında, ortalamalar arası farkın anlamlı olup olmadığına ilişkin yapılan ANOVA analizi sonucunda; araştırmaya katılan öğretmenlerinin Kaynaştırma Uygulamalarında Öğretmen Yeterlilikleri $(F=11,227, p<.05)$ ölçeğinde "özel eğitime ihtiyaç duyan öğrencilere eğitim verme tecrübesi” değişkenine göre. 05 anlamlılık düzeyinde pozitif yönde farklılaştığı belirlenmiştir. Levene testi sonuçları tablo varyansların homojen olduğunu (levene:1.988; p=.143) göstermektedir. Bu nedenle post-hoc menüsünden homojen varyanslı dağılımlarda örneklemlerin eşit olmadığı durumlarda kullanılan (Kayri, 2009) post-hoc tekniklerden "Scheffe" testi uygulanmıştır.

\section{Tablo 10}

Eğitim verme tecrübesi değişkenine göre fark oluşturan gruplara ait "LSD post-hoc testi” sonuçları

\begin{tabular}{lcccc}
\hline (I) ozlegtmtecrube & (J) ozlegtmtecrube & Ort. Fark (I-J) & Sh. & p. \\
\hline \multirow{2}{*}{ Hiç } & biraz & .28947 & 2.16854 & .991 \\
\multirow{2}{*}{ Biraz } & üst30+gün & $-13.13910^{*}$ & 3.02820 & .000 \\
& hiç & -.28947 & 2.16854 & .991 \\
\multirow{2}{*}{ üst30+gün } & üst30+gün & $-13.42857^{*}$ & 2.98912 & .000 \\
& hiç & $13.13910^{*}$ & 3.02820 & .000 \\
\hline
\end{tabular}

Tablo 10'e bakıldığında öğretmenlerinin kaynaştırma uygulamalarında öğretmen yeterlilikleri ölçeğinin özel eğitime ihtiyaç duyan öğrencilere eğitim verme değişkenine ilişkin LSD post-hoc testi uygulanmıştır. Elde edilen bulgulara göre Eğitim verme süresi 'Üst' (en az 30 tam gün üstü) olan öğretmenlerinin kaynaştırma uygulamalarında öğretmen yeterliliği ile eğitim verme süresi Biraz (0-30 gün) ve Hiç olan okul öncesi öğretmenlerinin öğretmen yeterliliği ortalama farkından daha yüksek olduğu tespit edilmiştir.

Özel eğitime ilişkin mevzuat ve politikalara dair bilgi düzeyi değişkenine göre. Bu değişkene göre alt problem "Öğretmenlerin kaynaştırma uygulamalarına ilişkin mevzuat ve politikalara dair bilgi düzeyi ile öğretmen yeterlilikleri arasında fark var mıdır?” şeklindedir. Bu alt probleme göre grup ANOVA analizi sonuçları Tablo 11'de ve “LSD post-hoc testi” Tablo 12'da yer almaktadır. 


\section{Tablo 11}

Öğretmenlerinin kaynaştırma uygulamalarında öğretmen yeterliliklerinin kaynaştırma uygulamalarına ilişsin mevzuat ve politikalara dair bilgi düzeyi değişkenine göre ANOVA sonuçları

\begin{tabular}{ccccccc}
\hline Ölçek & Mevzuat & Kareler Top. & $\boldsymbol{d} \boldsymbol{f}$ & Kareler Ort. & $\boldsymbol{F}$ & $\boldsymbol{p}$ \\
\hline & Gruplar Arası & 2434.102 & 3 & 811.367 & & \\
Öğretmen Yeterlilikleri & Gruplar İçi & 8209.610 & 90 & 91.218 & 8.895 & .000 \\
& Toplam & 10643.713 & 93 & & & \\
\hline
\end{tabular}

$* \mathrm{p}<.05$

Tablo 11'a bakıldığında, ortalamalar arası farkın anlamlı olup olmadığına ilişkin yapılan ANOVA analizi sonucunda; araştırmaya katılan öğretmenlerinin Kaynaştırma Uygulamalarında Öğretmen Yeterlilikleri ( $\mathrm{F}=8,895, \mathrm{p}<.05)$ ölçeğinde "kaynaştırma uygulamalarına ilişkin mevzuat ve politikalara dair bilgi düzeyi" değişkenine göre. 05 anlamlılık düzeyinde pozitif yönde farklılaştığı belirlenmiștir. Levene testi sonuçlarına göre tablo varyansları homojendir (levene:2.504; p=.064). Bu nedenle post-hoc analizinde homojen varyansh dağılımlarda örneklem sayısının eşit olmadığı durumlarda kullanılan (Kayri, 2009) post-hoc tekniklerden "Scheffe" testi uygulanmıştır.

\section{Tablo 12}

Öğretmenlerin kaynaştırma uygulamalarına ilişkin mevzuat ve politikalara dair bilgi düzeyi değgişkenine göre fark oluşturan gruplara ait "LSD Post-Hoc Testi" sonuçları

\begin{tabular}{ccccc}
\hline (I) mevzuat & (J) mevzuat & Ort. Fark (I-J) & Sh. & $\boldsymbol{p .}$ \\
\hline \multirow{2}{*}{ Hiç } & zayıf & $-8.09259^{*}$ & 2.43152 & .015 \\
& orta & $-11.13282^{*}$ & 2.55419 & .001 \\
& iyi & $-23.92593^{*}$ & 6.99910 & .011 \\
\multirow{2}{*}{ Zaylf } & hiç & $8.09259^{*}$ & 2.43152 & .015 \\
& orta & -3.04023 & 2.38312 & .654 \\
& iyi & -15.83333 & 6.93850 & .165 \\
Orta & hiç & $11.13282^{*}$ & 2.55419 & .001 \\
& zaylf & 3.04023 & 2.38312 & .654 \\
& iyi & -12.79310 & 6.98243 & .346 \\
İyi & hiç & $23.92593^{*}$ & 6.99910 & .011 \\
& zayıf & 15.83333 & 6.93850 & .165 \\
& orta & 12.79310 & 6.98243 & .346 \\
\hline
\end{tabular}

Tablo 12'a bakıldığında öğretmenlerinin kaynaştırma uygulamalarında öğretmen yeterlilikleri ölçeğinin kaynaştırma uygulamalarına ilişkin politika ve mevzuat bilgi düzeyi değişkenine yönelik LSD post-hoc testi yapılmış ve anlamlı bir şekilde farklılaștığı görülmüștür. Mevzuat ve politikalara dair hiç bilgi sahibi olmayan öğretmenlerin öğretmen yeterliliklerinin zayıf, orta ve iyi derecede bilgi düzeyine sahip olan öğretmenlerden anlamlı bir şekilde farklılaştığı görülmektedir. Mevzuat ve politikalara dair bilgi düzeyinin zayıf, orta ve iyi düzeyde olduğunu ifade eden öğretmenlerin yeterlilik düzeylerinin hiç bilgi sahibi olmayan öğretmenlere göre 
anlamlı düzeyde farklılaştığı görülmektedir. Betimsel istatistik sonuçlarına bakıldığında öğretmenlerin mevzuat ve politikalara dair bilgi düzeyleri arttıkça öğretmen yeterliliklerine ilişkin toplam puanlarının da arttığı tespit edilmiştir. Değişkenler arasındaki ilişkinin incelenmesi amacıyla yapılan "Pearson Çarpım Momentler Korelasyon katsayısı analizi” sonuçlarına göre öğretmen yeterlilikleri ile özel eğitim konusundaki tecrübe ve özel eğitime ilişkin politika ve mevzuat bilgisi değişkeni arasında pozitif yönde anlamlı ilişki bulunmaktadır. Bu analize yönelik bulgular Tablo 13'de gösterilmiştir.

\section{Tablo 13}

Öğretmenlerin kaynaştırma eğitimine tecrübe, mevzuata ve politikalara ilişsin bilgi düzeyleri ile kaynaştırma uygulamalarında öğretmen yeterlilikleri arasındaki korelasyon katsayıları (N=94)

\begin{tabular}{lccc}
\hline & 1 & 2 & 3 \\
\hline 1.Öğretmen Yeterlilikleri & 1 & & \\
2.Özel Eğitim Tecrübe & $.326^{* *}$ & 1 & \\
3.Mevzuat Bilgisi & $.457^{* *}$ & $.380^{* *}$ & 1 \\
\hline${ }^{* *} \mathrm{p}<.01$ & &
\end{tabular}

\section{TARTIŞMA, SONUÇ ve ÖNERİLER}

Her yıl daha fazla özel gereksinimli öğrencinin eğitime dahil olmasılyla (MEB,2020), öğretmenlerin eğitim vermekte olduğu öğrenci sayısı da giderek artmaktadır.Yapılan araştırmalar öğretmenlerin kaynaştırma eğitimi sürecinde mesleki bilgi eksikliğine bağlı olarak bir çok problemle karşılaştıklarını göstermektedir (Gebhardt, 2015; Kargın, Güldenoğlu ve Şahin, 2010; Patton ve Dowdy, 2008; Smith, Polloway, Rosenberg, Westling ve McLeskey, 2008; Zulfija, Indira ve Elmira, 2013). (Kuyumcu, 2011) öğretmen yeterlilikleri konusunda daha çok araştırma yapılması ve bilgi eksikliklerine ilişkin yaşadıkları sorunlarda daha çok hizmet içi eğitimin gerekliliğini belirtmektedir. Yapılan araştırmalarda öğretmenlerin özel eğitim konusundaki mesleki yeterlilikleri arttıkça öğrenci başarısının da arttığı görülmektedir(Feng ve Sass, 2013;Cooc,2019). Ülkemizde son dönemlerde yapılan araştırmalar genel olarak okul öncesi ve ilkokul düzeyinde yoğunlaşmaktadır (Gezer ve Aksoy, 2019; Kuyumcu, 2011; Özcan, 2020; Özder ve İnceler, 2020, Ünsal, 2019). Ülkemizde kaynaștırma öğrencileri ortaokuldan sonra meslek edindirmek amacıyla meslek liselerine yönlendirilmektedir. Bu bağlamda meslek lisesinde eğitim veren öğretmenlerin kaynaştırma eğitimi konusundaki yeterliliklerinin araştırıldığı bu çalışma alanyazındaki boşluğa katkı sağlamayı amaçlamaktadır.

Yapılan araştırma bulguları meslek liselerinde kaynaştırma öğrencilerine eğitim vermekte olan branş öğretmenlerinin büyük bir çoğunluğunun (\%77.7), bu konuda herhangi bir eğitim almadığını göstermektedir. Ayrıca kaynaştırma eğitimi konusundaki politika ve mevzuatlara ilişkin bilgi düzeyi açısında öğretmenlerin \%68 gibi bir çoğunluğunun bu konuda zayıf olduğu bulgusuna ulaşılmıştır. Bu bulgular öğretmenlerin bu konuda hizmet içi eğitime ihtiyaç duyduğunu göstermektedir.

Birinci araștırma sorusu bulgularına göre meslek liselerinde görev yapan öğretmenlerin kendilerini kaynaştırma eğitimi konusunda yeterli olarak tanımlamaktadır. Ancak genel yeterlilik ortalamalarına göre 108 
puan üzerinde 78.11 puan alan öğretmenlerin özellikle kaynaştırma eğitimi sürecinde diğer kişilerle işbirliği konusunda yeterliliklerinin geliştirilmesi gerektiği göze çarpmaktadır. Öğretmen yeterliliklerinin diğer değişkenler açısından değerlendirildiği ikinci araştırma sorusu bulgularına göre öğretmenlerin, yaș, öğrenim durumu, özel gereksinimli öğrencilerle etkileşim ve bu konuda alınan eğitim gibi değişkenlerin öğretmenlerin yeterlilikleri ile herhangi bir fark bulunmadığı görülmektedir. Öğretmenlerin özel gereksinimli öğrencilere ders verme tecrübesi ve özel eğitime ilişkin mevzuat ve politika bilgisi ile öğretmen yeterlilikleri arasında anlamlı fark bulunurken yapılan korelasyon testi sonuçlarına göre tecrübe ve mevzuat bilgisi arttıkça öğretmen yeterlilikleri puanlarının da arttığı görülmektedir. Bu bulgu LeRoy and Simpson 1996; Unianu (2012) ve Todorovic, Stojiljkovic, Ristanic ve Djigic (2011) tarafından yapılan araştırma bulguları ile benzer niteliktedir.

MEB (2020) verilerine göre 300 bini aşkın öğrencinin kaynaştırma öğrencisi olarak eğitim gördüğü ülkemizde bu sayı birçok ülkenin toplam öğrenci nüfusuna eş değerdir. Bu bağlamda kaynaştırma eğitiminde öğretmen yeterlilikleri her kademede araştırılması ve geliştirilmesi gereken bir konudur. Milli Eğitim Bakanlığının 2020 verilerine göre ortaokullarda 14200 olan örgün öğretim kaynaştırma öğrencisi sayısının liselerde 55000 civarına düşmesi bu kademede kaynaştırma öğrencilerinde okul terki ya da açık öğretime geçiş konusuyla ilgili bir probleme işaret etmektedir. Öğretmen yeterlilikleri ve kaynaştırma öğrencilerinin okul terki arasındaki ilişkinin araştırılması bu araştırmanın ortaya çıkardığı öneriler arasındadır. Bu araştırma bulgularında ulaşılan bir başka kayda değer konu ise tamamı kaynaştırma öğrencilerinin dersine giren öğretmenlerinin büyük çoğunluğunun bu konuda hiçbir eğitim almamış olmasıdır. Ayrıca özel eğitim konusunda alınan eğitim ile öğretmen yeterlilikleri arasında herhangi bir fark olmaması ülkemizde öğretmenlere bu konuda verilen eğitimin içerik ve etkililiğinin sorgulanmasını gerektirmektedir. Eğitim fakültelerinde ve öğretmenlerin hizmet içi eğitim programlarında özel eğitim konusundaki eğitim içeriklerinin araştırılarak yeniden düzenlenmesi konusunda çalışmalar yapılması bu araştırmada ortaya çıkan başka bir öneridir. Zulfija, Indira ve Elmira (2013) tarafından yapılan araştırmada kaynaştırma eğitimde çalışacak olan eğitimcilerin normal gelişimi olan çocuklar ve özel gereksinimli çocuklardan oluşan bir ekipte çalışma düzenleyebilmek, gerekli ölçme ve değerlendirme yöntemlerini geliştirebilmek gibi becerilerinin üniversite aşamasında edinilmesi gerektiğini belirtmektedir. Öğretmen yeterlilikleri ölçeğinde en düşük puanın işbirliği konusundaki yeterlilikler olması Taşdemir ve Özbesler,(2017)'in özel gereksinimli öğrencilerin okul ve aile arasındaki koordinasyonunun daha güçlü olması gerektiği görüşünü desteklemektedir.

Araştırmadan elde edilen bulgular, ülkemizde örgün öğretimde sayıları her geçen yıl artmakta olan kaynaştırma öğrencilerinin eğitimi esnasında nicelikle birlikte niteliğin de geliştirilmesi gerektiğini göstermektedir. Sayıları yüzbinleri bulan kaynaştırma öğrencilerinin meslek liselerinde mesleki eğitim alarak profesyonel yaşama dahil olmaları hem bireysel hem de toplumsal açıdan oldukça önemlidir. Bu bağlamda öğrencilerin bireysel özelliklerine uygun nitelikli eğitim verilebilmesi için bu kurumlarda öğretmen yeterliliklerinin arttırılması gereklidir. Bakanlığın diğer kurumlarla işbirliği içerisinde hareket ederek uygulamalı eğitimler organize etmesi ve bu okullarda görev yapan tüm öğretmenlerin kaynaştırma eğitimi 
konusunda donanımlı hale gelmesini sağlaması gereklidir. Araştırma bulgularında yer alan işbirliği yeterliliği algısının düşük olması, bu konuda kurumlar, öğretmenler, aileler, alan uzmanları ve sivil toplum kuruluşlarının bir araya gelerek özel gereksinimli bireylerin mesleki eğitimi ve iş yaşamına entegrasyonu konusunda daha somut adımlar atmaları gerektiğini göstermektedir. Bu araştırmaların kaynaştırma eğitimi verilen tüm kurumlarda uygulanarak gerekli görülen kurumlarda eğitim niteliğinin arttırılması ile ilgili çalışmalar yapılması bu araștırmada ortaya çıkan başka bir öneridir.

$\mathrm{Bu}$ araştırma İstanbul ili, Çekmeköy ilçesinde görev yapan 9. Sınıflarda kaynaştırma öğrencilerinin dersine giren öğretmenlerle sınırlı olup, veri toplama araçlarının ölçmeyi amaçladığı verilerle sınırlıdır. Yapılan araştırma; farklı illerde ve ek ölçme araçları kullanılarak gerçekleştirildiğinde çıkan genişletilmiş sonuçların konu ile ilgili literatüre katkı sağlayacağı düşünülmektedir. 


\section{KAYNAKÇA}

Ahsan, T. V. ve Sharma, U. (2018). Pre-service teachers' attitudes towards inclusion of students with high support needs in regular classrooms in Bangladesh. British Journal of Special Education, 45(1), 81-97. https://doi.org/10.1111/1467-8578.12211

Akalın, S., Demir, Ş., Sucuoğlu, B., Bakkaloğlu, H. V. ve İşcen, F. (2014). The needs of inclusive preschool teachers about inclusive practices. Eurasian Journal of Educational Research, 54,39-60. https://doi.org/10.14689/ejer.2014.54.3

Batu, E. S. (2000). Kaynaştırma, destek hizmetler ve kaynaştırmaya hazırlık etkinlikleri. Ankara Üniversitesi Eğitim Bilimleri Fakültesi Özel Eğitim Dergisi, 2(4), 35-45. https://doi.org/10.1501/Ozlegt_0000000050

Bayar, A. (2015). Kaynaştırma Uygulamalarında Öğretmen Yeterliği Ölçeği'nin Türkçeye uyarlama, geçerlik ve güvenirlik çalıșması. Ahi Evran Üniversitesi Kırşehir Eğitim Fakültesi Dergisi (KEFAD), 16(3), 71-85.

Begeny, J. ve Martens, B. (2007). Inclusionary education in Italy: a literature review and call for more. Empirical $\begin{array}{llll}\text { Research Remedial and Special } & \text { Education, }\end{array}$ https://doi.org/10.1177/07419325070280020701

Çerezci, Ö. (2015). Okul öncesi eğitim kurumlarında yapılan kaynaştırma eğitimi uygulamalarının kaynaştırma kriterleri açısından değerlendirilmesi [Yayımlanmamış yüksek lisans tezi]. Gazi Üniversitesi.

Çetin, M. (2020). Öğretmen adaylarının kaynaştırma eğitimine yönelik görüşlerinin ve yeterlik düzeylerinin belirlenmesi [Yayımlanmamış yüksek lisans tezi]. Balıkesir Üniversitesi.

Cooc, N. (2019). Teaching students with special needs: international trends in school capacity and the need for teacher professional development. Teaching and Teacher Education, 83, 27-41. https://doi.org/10.1016/j.tate.2019.03.021

Deng, M. ve Manset, G. (2000). Analysis of the "learning in regular classrooms" movement in China. Mental Retardation, 38(2), 124-130 https://doi.org/10.1352/0047-6765(2000)038

Dixon, R. ve Verenikina, I. (2007). Towards inclusive schools: an examination of socio-culturaltheory and inclusive practices and policy in New SouthWales DET schools. Learning and Sociocultural Theory: Exploring Modern Vygotskian Perspectives International Workshop, 1(1), 191-208.

European Agency. (2019, Aralık 24). Data tables and background information https://www.europeanagency.org/data/data-tables-background-information

Farrell, P. (2000). The impact of research on developments in inclusive education. International Journal of Inclusive Education, 4(2), 153-162 https://doi.org/10.1080/136031100284867 
Feng L. ve Sass T.R. (2013). What makes special-education teachers special? Teacher training of students with $\begin{array}{llllll}\text { disabilities, } & \text { Economics } & \text { of } & \text { Education } & \text { Review. } & 36,\end{array}$ https://doi.org/10.1016/j.econedurev.2013.06.006

Fiscus, D. E. ve Mandell, J. C. (2002). Bireyselleştirilmiş eğitim programlarının geliştirilmesi. (Development of individualized education programs) (G. Akçamete, H. G. Şenel ve E. Tekin, Çev. Anı Yayıncılık.

Forlin, C. ve K. Sin. (2010). Developing support for inclusion: a professional learning approach for teachers in Hong Kong. International Journal of Whole Schooling, 6(1), 7-26.

Gebhart, M. (2015). General and special education teachers' perceptions of teamwork in inclusive classrooms at elementary and secondary schools. Journal for Educational Research Online, 7(5), 129-146.

Gezer, M. S. (2017). Sinıfında kaynaştırma öğrencisi bulunan okul öncesi öğretmenlerinin kaynaştırma eğitimine yönelik rol algılarının incelenmesi [Yayımlanmamış yüksek lisans tezi]. Anadolu Üniversitesi.

Gezer, M. S. ve Aksoy V. (2019). Perceptions of Turkish preschool teachers' about their roles within the context of inclusive education. International Journal of Early Childhood Special Education, 11(1), 31-42 https://doi.org/10.20489/intjecse.583541

Gök, G. ve Erbaş, D. (2011). Okulöncesi eğitimi öğretmenlerinin kaynaştırma eğitimine ilişkin görüşleri ve önerileri. International Journal of Early Childhood Special Education, 3(1), 66-87 https://doi.org/10.17679/inuefd.306517

Government of United Kingdom Report, (2020, Aralık 20), http://www.direct.gov.uk/en/Parents/Schoolslearninganddevelopment/SpecialEducationalNeeds/DG_ 4008600

İnsan $\quad$ Hakları $\quad$ Evrensel $\quad$ Bildirgesi $\quad$ (1948). $\quad$ Erişim $\quad$ tarihi:15.01.2021 https://www.tbmm.gov.tr/komisyon/insanhaklari/pdf01/203-208.pdf

İra, N. ve Ayan, B. (2016). Ortaöğretim Okullarındaki Kaynaştırma Uygulamalarının Değerlendirilmesi. Kocaeli Üniversitesi Sosyal Bilimler Enstitüsü Dergisi, 31, 145-160.

Karaca, M. A. (2018). Kaynaştırma eğitimi programının öğretmenlerin kaynaştırma uygulamalarındaki mesleki yeterliliklerine etkisi [Yayımlanmamış yüksek lisans tezi]. Necmettin Erbakan Üniversitesi.

Karagiannis, A., Stainback, W. ve Stainback, S. (1996). Rationale for inclusive schooling. Inclusion: A guide for educators. Brookes.

Karasar, N. (2006). Bilimsel araştırma yöntemi. Nobel Yayın Dağıtım.

Kargin, T., Güldenoglu, B. ve Şahin, F. (2010). Genel eğitim sınıflarındaki özel gereksinimli öğrenciler için yapılması gereken uyarlamalara ilişkin sınıf öğretmenlerinin görüşlerinin incelenmesi. Kuram ve Uygulamada Ë̆itim Bilimleri, 10(4), 2431-2464. 
Kayri, M. (2009). Araştırmalarda gruplar arası farkın belirlenmesine yönelik çoklu karşılaştırma (Post-Hoc) teknikleri. Fırat Üniversitesi Sosyal Bilimler Dergisi, 19(1), 51-64.

Kuyumcu, Z. (2011). Bireyselleştirilmiş eğitim planı (BEP) geliştirilmesi ve uygulanması sürecinde öğretmenlerin yaşadıkları sorunlar ve bu sorunlara yönelik çözüm önerileri [Yayımlanmamış yüksek lisans tezi]. Ankara Üniversitesi.

Lasagabaster, D. ve Zarobe Y.R. (2010). CLIL in Spain, implementation, results and teacher training. Cambridge Scholars Publishing.

Le Roy, B. ve Simpson C. (1996). Improving student outcomes through inclusive education. Support for Learning, 11(1), 32-36. https://doi.org/10.1111/j.1467-9604.1996.tb00046.x

Leeuw, R.R., Boer, A. A. ve Minnaert A.E.M.G. (2018). Student voices on social exclusion in general primary schools. European Journal of Special Needs Education, 33(2), 166-186. https://doi.org/10.1080/08856257.2018.1424783

MEB(1983). Milli Eğitim Temel Kanunu. Erişim tarihi:15.01.2021 https://www.kanunum.com/files/2916-1.pdf

MEB(2004). Bireyselleștirilmiş̧ eğitim programı yol haritası. Erişim Tarihi: 20.12.2020 https://orgm.meb.gov.tr/meb_iys_dosyalar/2013_09/18015222_bireyselletirilmieitimprogram.pdf

MEB(2010). Okullarımızda 3N Neden, Nasıl, Niçin Kaynaştırma. Erişim tarihi: 18.12.2020 https://orgm.meb.gov.tr/alt_sayfalar/yayimlar/kaynastirma/kaynastirma.pdf

MEB(2012). Özel Eğitim Yönetmeliği. Ankara: MEB Yayınları

MEB(2016). Özel Eğitim ve Rehberlik Hizmetleri Genel müdürlüğü Erişim tarihi:12.10.2018 http://orgm.meb.gov.tr/meb_iys_dosyalar/2018_07/09101900_ozel_egitim_hizmetleri_yonetmeligi_ 07072018.pdf

Metin, N, Güleç, H. ve Şahin, Ç. (2020, Aralık 15). İlköğretim öğretmenlerinin zihinsel engelli çocukların kaynaştırılmasına yönelik almış oldukları hizmet içi eğitim sonrasında yeterliliklerinin belirlenmesi. http://www.eab.org.tr/eab/2009/pdf/279.pdf

MEXT.(2020,

Aralık

12).

Kyoshokukateinint. http://www.mext.go.jp/component/a_menu/education/detail/_icsFiles/afieldfile/2018/01/16/139904 7.pdf.

Milli Eğitim Temel Kanunu (1973). $\quad$ Erişim $\quad$ tarihi: 15.10 .2018 https://www.mevzuat.gov.tr/MevzuatMetin/1.5.1739.pdf 
Mulholland, S. ve Cumming, M.T. (2016). Investigating teacher attitudes of disability using a non-traditional theoretical framework of attitude. International Journal of Education and Research, 80, 93-100. https://doi.org/10.1016/j.ijer.2016.10.001

OECD (2010). Education at a Glance 2010: OECD Indicators

Özcan, İ. (2020). Okul öncesi öğretmenlerinin kaynaştırma eğitimine yönelik duyguları tutumları ve kaygıları ile kaynaştırma uygulamalarındaki öğretmen yeterlilikleri arasındaki ilişskinin incelenmesi (Çankırı ili örneği) [Yayımlanmamış yüksek lisans tezi]. Pamukkale Üniversitesi.

Özder, H. ve İnceler, H.(2020). Öğretmen adaylarının kaynaştırma eğitimine ilişkin tutumlarının incelenmesi: KKTC örneği. İnönü Üniversitesi Eğitim Fakültesi Dergisi, 21(2), 719-739. https://doi.org/10.17679/inuefd.654127

Özel Eğitim Hakkında Kanun Hükmünde Kararname (1997). Erişim tarihi:19.10.2018 https://www.mevzuat.gov.tr/MevzuatMetin/4.5.573.pdf

Özel Eğitime Muhtaç Çocuklar Kanunu (1983). T.C. Resmi Gazete (181192, 15 Ekim 1983) Erişim Tarihi: 19.10.2018. https://www.resmigazete.gov.tr/arsiv/18192.pdf

Paloshi, A. I., Vasileska L., Trpceska L., Spasovski, G. Aleksova R. S. ve Crabtree D.(2014). Inclusion in secondary vocational education, Handbook on working with special educational needs students. British Council.

Pektaş, H. (2008). Özel eğitim programlarından ve farklı programlardan mezun öğretmenlerin bireyselleştirilmiş eğitim programı kullanma durumlarının saptanması [Yayımlanmamış yüksek lisans tezi]. Gazi Üniversitesi.

Rosenberg, M., Westling, D. ve McLeskey, J. (2008). Special education for today's teachers. Prentice Hall.

Saloviita, T. (2020a). Attitudes of teachers towards inclusive education in Finland. Scandinavian Journal of Educatıonal Research, 64(2), 270-282. https://doi.org/10.1080/00313831.2018.1541819

Saloviita. T. (2020b). Teacher attitudes towards the inclusion of students with support needs. Journal of Research and Special Education Needs, 20, 64-73. https://doi.org/10.1111/1471-3802.12466

Şen, R. (2016). Meslek liselerinde çalışan öğretmenlerin kaynaştırmaya iliş̧in sorunları, çözüm önerileri ve beklentileri [Yayımlanmamış yüksek lisans tezi]. Aydın Üniversitesi.

Sharma, U., Loreman, T. ve Forlin, C. (2011). Measuring teacher efficacy to implement inclusive practices. Journal of Research in Special Educational Needs, 12(1), 12-21. https://doi.org/10.1111/j.14713802.2011.01200.x

Sin, K. F., Tsang, K. W. ve Lai, C. L.(2010). Upskilling all mainstream teachers: what is viable?" in teacher education for inclusion:changing paradigms and innovative approaches. Routledge. 
Sipahi, B. Yurtkoru, E. S. ve Çinko, M. (2008). Sosyal bilimlerde SPSS'le veri analizi. Beta Basım Yayım Dăğıtım.

Smith, E. C., Polloway, E., Patton, J. ve Dowdy, C. (2008). Teaching students with special needs in inclusive settings (5th ed). Allyn \& Bacon.

Snow, P. ve Powell, M. (2012). Youth (in)justice: oral language competence in early life and riskfor engagement in antisocial behaviour in adolescence. Trends and Issues in Crime and Criminal Justice, 435, 1-6.

Strateji Geliştirme Başkanlığı. (2020, Aralık 25). Millî Eğitim İstatistikleri Örgün Eğitim 2019-2020 http://sgb.meb.gov.tr/meb_iys_dosyalar/2020_09/04144812_meb_istatistikleri_orgun_egitim_2019_ 2020.pdf

Tabachnick, B. G. ve Fidell, L. S. (2013). Using multivariate statistics. Pearson.

Taşdemir, H. ve Özbesler. C. (2017). Kaynaştırma eğitimine devam eden çocukların karşılaştıkları sorunların okul ortamında sosyal hizmet uygulamaları perspektifinde değerlendirilmesi. Uluslararası Sosyal Araştırmalar Dergisi, 10(49), 498-507.

Todorovic, E., Stojiljkovic S., Ristanic S. ve Djigic G, (2011). Attitudes towards inclusive education and dimensions of teacher's personality, Procedia - Social and Behavioral Sciences, 29, 426-432. https://doi.org/10.1016/j.sbspro.2011.11.259

Ünal, F. ve Saban, A. (2017). Kaynaştırma uygulamasının yapıldığı sınıflarda, öğretmenlerin kaynaştırmaya yönelik tutumları. C..Ü. Sosyal Bilimler Enstitüsü Dergisi, 23(1), 388-405.

UNESCO.(1990). World declaration on education for all. Erişim tarihi:28.07.2019 http://www.unesco.org/education/efa/ed_for_all/background/jomtien_declaration.shtml

UNESCO.(1994). The Salamanca statement and framework for action on special needs education:Paris

UNESCO.(2003). Overcoming exclusion through inclusive approaches in education. A challenge and a vision: Paris

Unianu, E. M.(2012). Teachers' attitudes towards inclusive education. Procedia - Social and Behavioral Sciences, 33, 900-904. https://doi.org/10.1016/j.sbspro.2012.01.252

Ünsal, K. (2019). Kaynaştırma/bütünleştirme yoluyla eğitim uygulamalarında rol alan sınıf öğretmenlerinin görev ve sorumluluklarını yerine getirme durumları ile kaynaştırmaya yönelik tutumlarının incelenmesi [Yayımlanmamış yüksek lisans tezi]. Ağrı İbrahim Çeçen Üniversitesi.

Varol, (2010). Milli Eğitim Bakanlığı Eğitimi Araștırma Ve Geliştirme Dairesi Başkanlı̆̆ı, ilköğretim okullarındaki kaynaştırma uygulamalarının değerlendirilmesi. Erişim tarihi: 10.10 .2018 https://www.meb.gov.tr/earged/earged/ilk_kaynas_eg_uyg_deg.pdf 
Waitoller, F. V. ve Artiles, A. (2013). A decade of professional development research for inclusive education: a critical review and notes for a research program. Review of Education Research, 183(3), 319-356. https://doi.org/10.3102/0034654313483905

Wilkinson, R. ve Pickett, K. (2010). The spirit level: why equality is better for everyone. Penguin.

Yazıcıoğlu, T. (2018). Kaynaştırma uygulamalarının tarihsel süreci ve Türkiye'de uygulanan kaynaştırma modelleri. Nevşehir Hacı Bektaş Veli Üniversitesi SBE Dergisi, 8(1), $92 \quad$ - 110. https://doi.org/10.30783/nevsosbilen.420028

Zulfija, M., Indira O. ve Uaidullakyzy, E.(2013). The professional competence of teachers in inclusive education. Procedia - Social and Behavioral Sciences, 89, 549-554. https://doi.org/10.1016/j.sbspro.2013.08.892 


\section{EXTENDED ABSTRACT}

\section{Introduction.}

Regarding the concepts of "equality of opportunity " in education, which is clearly emphasized by the Universal Declaration of Human Rights and the Basic Law of National Education of our country, students with special needs should receive education in the same environment with their normally developing peers. They should also benefit from the same education and training opportunities that they benefit. The students in need of special education receive education together with their peers in formal education classes as part-time and full-time inclusive students within the framework of their individual needs in collaboration with branch teachers and school counselors (Varol, 2010).The studies conducted by researchers who advocate inclusive education, reveal that the application of inclusive education improves both the academic and social skills of students with special needs and prepares them better for the social life. Moreover, it has been observed that the negative effects resulting from social exclusion in students who are subjected to inclusive education are minimal (Farrell, 2000; Karagiannis et. al., 1996). Ahsan and Sharma (2018), De Leeuw et. al., (2018), Mulholland and Cumming (2016) and Saloviita (2020) also emphasize the positive effects of inclusive education on the affective development of students.

One of the most important factors for the success of inclusive education is the competence level of teachers on special education who teach in inclusive classes (Bayar, 2015). It has been observed by various researchers that branch teachers, who have very limited education and knowledge about the special education experience problems in different aspects of inclusive education (Çerezci, 2015; Gezer, 2017; Gök ve Erbaș, 2011; Karaca, 2018). Considering that the teachers in the study group teach at the high school level, in the case of their incompetence on the subject, inclusive education, which requires a specialization in itself, can be an important problem when combined with the problems caused by the adolescence period of high school students.

The aim of this study is to reveal the self-efficacy perceptions of 9th grade branch teachers teaching in vocational high schools where inclusive students are educated. The relation between the teachers' self-efficiacy perceptions and their age, interaction status with the inclusive students, their education level on special education, their teaching experience period in iclusive classes and their knowledge level on policies and legislation about inclusive education are also investigated.

\section{Method.}

The study group of the research consists of 94 branch teachers who teach at the 9 th grade of vocational high schools in Çekmeköy district of Istanbul in 2018-2019 and have a total of 48 inclusive students in their classes. Within the scope of this study a personal information form and Teacher Competence Scale in Inclusive Practices were applied to teachers. The quantitative data collected through the scales were analyzed using the 
SPSS 22.0 statistical program. Independent Sample T-Test, One-Way Analysis of Variance (ANOVA) and LSD Tests and Correlation Test.

\section{Results.}

The findings of the research reveal that the vast majority (77.7\%) of the branch teachers who are educating inclusive students in vocational high schools do not receive any training on special education. In addition, it was found that $68 \%$ of the teachers define themselves as poor in terms of the level of knowledge on policies and legislation on inclusive education. These findings show that most of the teachers need in-service training on the subject. According to the findings of this study, there is no significant difference between teachers' age, educational status, interaction status with the inclusive students, their education level on special education and self-efficiacy perceptions.On the other hand, a significant difference was found between teachers' experiences of special education and their level of knowledge on legislation and policies and their self-efficiacy perceptions. Accordingly, it was found that as the experience and knowledge level of teachers about legislation and policies increased, their self-efficiacy perceptions also increased.

\section{Discussion \& Conclusion.}

The findings of the study suggests that there is a need for improving the quality of education given to inclusive students whose number is increasing every year in formal education in our country. It is very important both individually and socially for inclusive students to participate in professional life by taking vocational training in vocational high schools. In this context, teacher competencies should be increased in these institutions in order to provide qualified education in accordance with the individual needs of students. The Ministry of National Education should cooperate with other institutions to organize practical trainings and ensure that all teachers working in these schools are equipped with inclusive education competencies.

The results of the study suggest that there is a need for training the teachers on the issues such as inclusive education and the related legislation. In addition, considering that the vast majority of teachers who attend inclusive students' courses stated that they did not receive any training on this subject, it is recommended to enrich the educational contents of education faculties with special education subjects. The research findings indicating the low perception of cooperation competence points out that teachers, families, field experts and non-governmental organizations should come together to take more concrete steps in the vocational education and integration of individuals with special needs into business life. 